ISSN 1112-9867

http://www.jfas.info

\title{
ASSESSMENT OF NUTRIENT CONTAMINATION IN SURFACE WATER, CASE STUDY OF AIN ZADA DAM (NORTH-EAST OF ALGERIA)
}

\author{
A. Mebarkia ${ }^{1 *}$, A. Haouchine ${ }^{1}$, A. Boudoukha ${ }^{2}$, and R. Nedjai ${ }^{3}$ \\ ${ }^{1}$ Geo-Environment Laboratory FSTGAT/USTHB, Bab-Ezzouar 16111Algiers, Algeria \\ ${ }^{2}$ Research Laboratory of Applied Hydraulics, University of Batna, Algeria \\ ${ }^{3}$ CEDETE laboratory, University of Orléans, 45067 Orléans Cedex 2, France
}

Received: 30 January 2017 / Accepted: 25 July 2017 / Published online: 01 September 2017

\begin{abstract}
In order to evaluate the impact of potential pollutions on the water quality in the watershed of the upstream of wadi Boussellem (North-east of Algeria), the evolution of the chemical composition of waters of the Ain Zada dam was studied over a period of ten years. Using a linear model of trends and a principal components analysis (PCA) methods, have been detected and quantified for the substances that are connected with the fertilizers and domestic effluents. An increasing concentration is observed for most of these substances. The increase of $88 \%$ in $\mathrm{COD}, 66 \%$ in $\mathrm{BOD}_{5}$ and the decrease of $4.3 \%$ in $\mathrm{pH}$, suggests a degradation of O.M $85 \%$ by microorganisms. This degradation was accompanied by a decrease of $2 \%$ of $\mathrm{O}_{2 \text { dis }}$ content. The large increases of E.C $76 \%, \mathrm{NH}_{4} 290 \%$ and $\mathrm{NO}_{2} 100 \%$, are related to a marked increase in fertilizers applications and the denitrification of $\mathrm{NO}_{3}$ where latters declined by $77 \%$. These increases are related also to the large amount of human and animal organic materials and industrial waste dumped.
\end{abstract}

Keywords: Pollution; Eutrophication; wadi Boussellem; microorganisms, fertilizers.

Author Correspondence, e-mail: hafid.19@hotmail.fr

doi: http://dx.doi.org/10.4314/jfas.v9i3.8 


\section{INTRODUCTION}

In Algeria, several reservoirs and dams are experiencing in recent years problems of degradation of water quality due mainly to the different sources of pollution [1-5], due to population growth, the expansion of the industrial fabric and agricultural development. Discharges from urban areas as well as plants often discharged directly in streams without any treatment. This is especially observed in developing countries where the cost of prior treatment of waste is prohibitive. Several studies have reported the effects of industrial and urban emanations on the evolution of the surface waters quality [6-9].

In the high plateaus region of Sétif, a large industrial, agricultural and urban activity develops throughout the entire OuedBoussellem watershed. The main river receives daily hundreds of cubic meters of waste that generate a total deterioration of the quality of surface waters in the region. This is why the aim of our study isto highlights the pollution of the dam Ain Zada by nutriments.

\section{GENERAL OVERVIEW}

With an area of $1800 \mathrm{~km}^{2}$, the watershed of wadi Boussellem is located in the north-east of Algeria (Fig.1.a). The dam of Ain Zada controls this basin, which is located some $25 \mathrm{~km}$ west of Setif city. The basin is characterized by ridges with peaks rising between $1050 \mathrm{~m}$ and $1737 \mathrm{~m}$. The zone between $1050 \mathrm{~m}$ in the north, $870 \mathrm{~m}$ in the central and the southern plains, presents a slope of about $3 \%$.

Of a geological stand point, this plain is largely covered with heterogeneous terrains formed by clays, silts, alluvium, and limestone crust. The age of these formations lasts from Miocene to Quaternary. Such recovery may reach a thickness of $500 \mathrm{~m}$ in some places. North and south boundaries are formed by carbonate terrains respectively belonging to the Tellian layers and the whole south Sétifian allochthonous [10]. The bulk of the watershed area (80\%) is occupied by land with low to medium permeability represented by very few sandy, clay, limestone and limestones lacustrine. The remaining $(20 \%)$ is occupied by impermeable formations represented by clays and marls (Fig.1.b). A stratigraphic column (Fig.1.c) of the study area; clarify the relationship between the different formations of the study area [11]. 


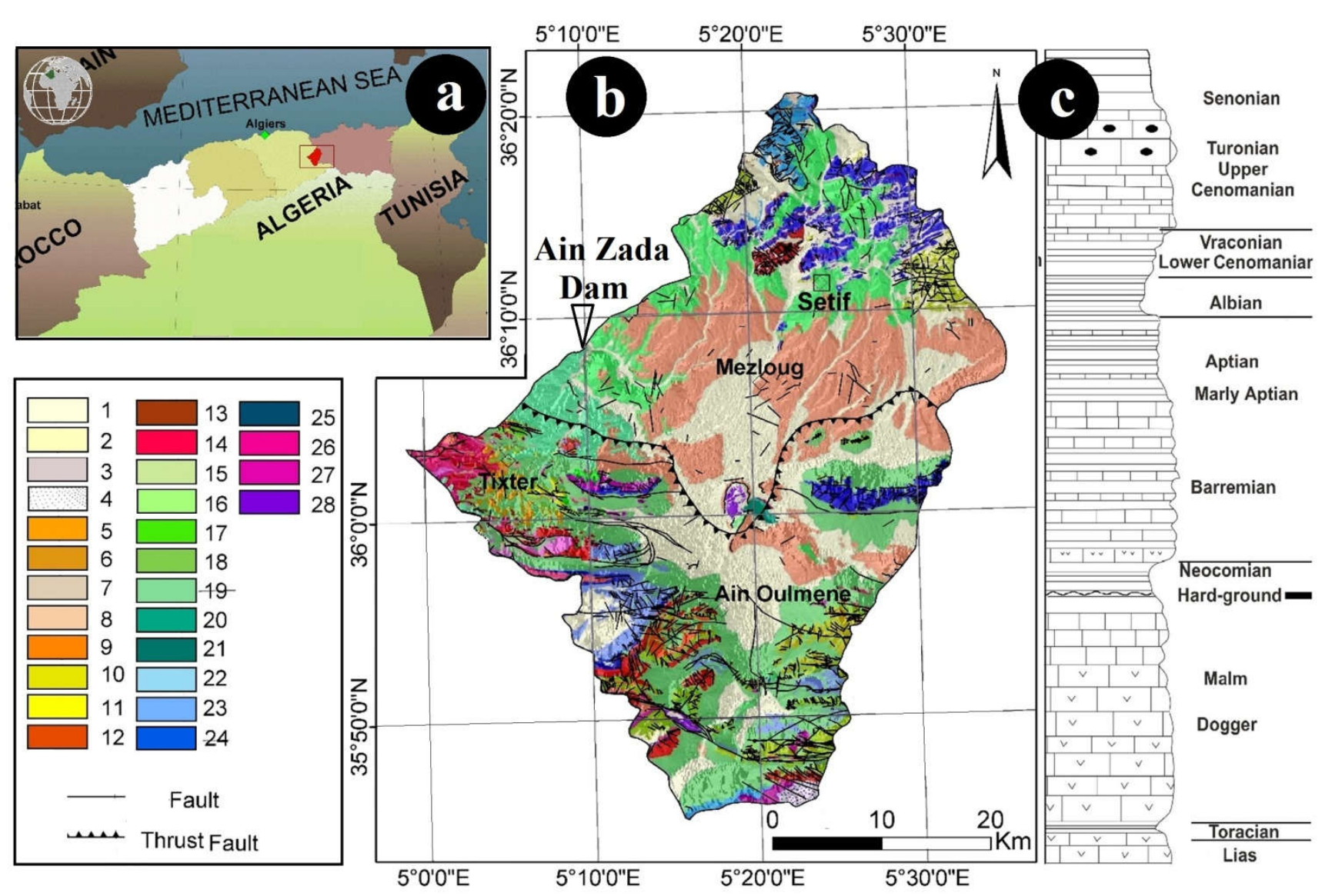

Fig.1. a: Geographical location of the study area; b: lithological map of the Boussellem

sub-watershed, c: stratigraphic column of the study area.

Map Caption: 1-Recent alluvium, 2-slope Unconsolidated formations;, Topsoil-3, 4-Slopes Screes, 5-Limestone with flints, 6-Blackish marl, 7-Brown and yellow limestone marl, 8-Bandy clays, 9-Yellowish marl, 10-Redhead sandstone and conglomerates, 11-Sandstones, 12 Sandy loam, 13-Marly and limestone tiles, 14 Yellow-marl, 15-Dolostone, 16-Black marl, 17-Marl and limestone sub lithographic, 18-Dolostone and limestone with flints, 19-Gray marl and limestone; 20-Marl and limestone; 21-Limestone; 22-Clay and sandstone benches; 23-Marly limestone tiles, 24-phosphatic white limestone, 25-dolostones, 26-Black marl, 27-Varicoloured clays and ground gypsum, 28-Fine limestone with Saccocommides.

In regards to the climate, the region is characterized by a semi-arid climate with a relatively temperate and cold winter and hot and dry summer, influenced by the humid air currents from the Mediterranean Sea in winter and hot from the Sahara in summer. The annual average temperature is $15^{\circ} \mathrm{C}$, with an average annual precipitation of about $359 \mathrm{~mm}$. The effective evaporation takes nearly $94 \%$ of precipitation, runoff and infiltration totalling the remaining $6 \%$ of the precipitated water.

The annual excess is of $20 \mathrm{~mm}$. This allows a steady flow of OuedBoussellem especially during 
periods of high water (January and February) with an average flow of $1.14 \mathrm{~m}^{3} / \mathrm{s}$ [8]. For the rest of the year, the region is subject to an irregular hydrological regime for the leaching of soluble chemicals, especially fertilizers and sewage from cities and urban centres with a mean annual flow of $0.42 \mathrm{~m}^{3} / \mathrm{s}$ measured at Farmatou station. This enables the reservoir to receive a large share of annual liquid flow in few weeks and then it becomes finally stagnant water where evaporation is the dominant factor.

The dam of Ain Zada is a rock fill dam with a capacity of $125 \mathrm{Mm}^{3}$; the withholding has an area of 1.140 hectares and a maximum depth of $26 \mathrm{~m}$. The vegetation of the watershed is very low, allowing thus during heavy rainfall to mobilize huge amounts of suspended material in addition to other basin soluble elements.

\section{MATERIALS AND METHODS}

\subsection{Sampling and Analytical Methods}

The main tasks of the National Water resources agency are to ensure the qualitative and quantitative conservation of water resources of Algerian dams. In this perspective and since 1980s, a program of physical and chemical analysis was undertaken in order to create a database. In addition, many hydrochemical data were acquired on surface water from the Boussellem watershed [12] and in the dam of Ain Zada. Our contribution focused solely on the characterization for the eventual organic pollution of urban and agricultural origin. In this context, we conducted a series of samples in order to monitor the quality of discharges into the receiving environment and to study the temporal variation of nutrients from these waters with the purpose of understanding the mechanisms of pollution. The sampling rate adopted during an observation period of ten years (January 2003 - December 2012) was 01 levy per month; 120 samples were thus collected. According to the sampling protocol, these samples are collected in polyethylene bottles, stored at $4{ }^{\circ} \mathrm{C}$ and transported to the laboratory within a period not exceeding 4 hours. Electrical conductivity, $\mathrm{pH}$, temperature and dissolved oxygen were measured in situ by means of a field multi-parameter WTW (ProfiLine Multi 3320).

The determination of nitrates, nitrites and phosphates concentrations is carried out by molecular absorption spectrometry, while the Ammonium is done by the spectrophotometric method with 
Nessler reagent. To measure the $\mathrm{BOD}_{5}$, is carried out a first measurement of the oxygen concentration in the water sample. This measurement is repeated 5 days later. The $\mathrm{BOD}_{5}$ represents the difference between the two concentrations. $\mathrm{BOD}_{5}$ and $\mathrm{COD}$ were analysed using an automated analyser the SP2000. All these analyses (Table1) were carried out by the technical staff of the laboratory of national agency of water resources (ANRH).

\subsection{Trends Method}

We can detect the water quality trends by averaging systematic monotonic changes in concentrations over a long period. Many studies have been achieved for such methods [13-15] but the methodologies for determining trends have not been developed in their works. Amongst the latter can be mentioned the work by Regnie (1965) [16-18].

The Regnie model based on the equations of the least squares linear trend, adjusts a chronological series $(\mathrm{Yt})$ with the function $\mathrm{Ct}=\mathrm{at}+\mathrm{b}$. The straight (trend) least squares $(y=a t+b)$ cloud point $(t, Y t)$ which minimizes the distance is determined $\Sigma(Y t-(a t+b))^{2}$. This method allows a better adjustment of the trend line and can compensate for the effects of floor noise produced by the short-term variations and distinguish the effects of runoff, seasonal changes and thus bringing out the possible effects of pollution from Original anthropogenic long term.

For the Ain Zada dam waters, the long-term trends have been quantified during the period 2003-2012 using linear regressions between monthly instantaneous concentrations and time. This treatment was performed using the model included in Microsoft Excel 2010, (Table1). 
Table 1. Statistical characteristics of physico-chemical data of Aïn Zada dam water from 2003 to 2012 .

\begin{tabular}{|c|c|c|c|c|c|c|c|c|c|c|c|c|}
\hline Parameters & Relation:C/t & $\mathrm{C}_{t 0}$ & $\mathbf{C}_{t f}$ & $\begin{array}{c}\text { Trends } \\
\%\end{array}$ & Min & $\operatorname{Max}$ & Mean & Median & S D & WHO.N & A.N & $\mathrm{CV}$ \\
\hline $\mathbf{P}(\mathbf{m m})$ & $P=-0.004 t+215.9$ & 43 & 26.3 & -38 & 0 & 137,90 & 34.81 & 27,05 & 27,64 & / & l & 0.03 \\
\hline $\operatorname{Vr}\left(\mathrm{Mm}^{3}\right)$ & $\mathrm{Vr}=-0.012 \mathrm{t}+578.4$ & 123 & 79 & -35 & 65.97 & 125,6 & 100.88 & 94,79 & 16.42 & l & / & 0.61 \\
\hline $\operatorname{air} \mathbf{T}^{\circ} \mathbf{C}$ & $\mathrm{T}=0.001 \mathrm{t}+1.857$ & 14.3 & 15.5 & +8.4 & 2 & 29 & 15 & 14,50 & 7.77 & & l & 0.002 \\
\hline Water $\mathbf{T}^{\circ} \mathbf{C}$ & $\mathrm{Tw}=0.001 \mathrm{t}+6.304$ & 16.7 & 17.7 & +6 & 5.5 & 30 & 17.23 & 17 & 6.9 & $<25$ & 25 & 0.001 \\
\hline E.C $(\mu \mathrm{S} / \mathrm{cm})$ & E.C $=0.171 \mathrm{t}-5612$ & 800 & 1410 & +76 & 600 & 1900 & 1158.58 & 1180 & 239.89 & 1500 & 2800 & 0.57 \\
\hline Rs & $\mathrm{Rs}=0.1 \mathrm{t}-3199$ & 576.5 & 938 & +62 & 400 & 1020 & 755.82 & 793 & 146.62 & 2000 & 2000 & 0.52 \\
\hline pH & $p H=-1 E-04 t+11.69$ & 8.06 & 7.71 & -4.3 & 6.97 & 8.5 & 7.88 & 7.90 & 0.3 & $6,5-8$ & $6.5-9$ & 0.12 \\
\hline $\mathrm{NO}_{3}^{-}(\mathrm{mg} / \mathrm{l})$ & $C=-0.001 t+39.65$ & 4.4 & 1 & -77 & 0.1 & 16 & 2.78 & 2 & 2.99 & 50 & 50 & 0.11 \\
\hline $\mathrm{NO}_{2}^{-}(\mathrm{mg} / \mathrm{l})$ & $C=2 E-05 t-0.546$ & 0.06 & 0.12 & +100 & 0.001 & 0.95 & 0.091 & 0.042 & 0.157 & $0.01-0.1$ & 0.1 & 0.01 \\
\hline $\mathrm{NH}_{4}{ }^{+}(\mathrm{mg} / \mathrm{l})$ & $\mathrm{C}=8 \mathrm{E}-05 \mathrm{t}-2.905$ & 0.1 & 0.39 & +290 & 0.01 & 2.04 & 0.246 & 0.06 & 0.377 & 0.5 & 0.5 & 0.1 \\
\hline $\mathrm{PO}_{4}{ }^{3-}(\mathrm{mg} / \mathrm{l})$ & $C=-4 E-05 t+1.748$ & 0.235 & 0.09 & -61 & 0.01 & 0.89 & 0.162 & 0.11 & 0.157 & $0.1-0.5$ & 0.5 & 0.07 \\
\hline O.M (mg/l) & $\mathrm{C}=0.001 \mathrm{t}-60.71$ & 7.7 & 14.3 & +85 & 1.6 & 18 & 11.01 & 11 & 3.22 & / & 5 & 0.36 \\
\hline $\mathrm{O}_{2 \mathrm{dis}}(\mathrm{mg} / \mathrm{l})$ & $C=-0.001 \mathrm{t}+33.63$ & 9.13 & 8.9 & -2 & 5 & 14.1 & 9.1 & 9.15 & 1.75 & 5 & 7 & 0.04 \\
\hline COD (mg/l) & $C=0.008 t-295.9$ & 36 & 68 & +88 & 10 & 109 & 52.44 & 53 & 20.82 & $20-25$ & 30 & 0.20 \\
\hline $\mathrm{BOD}_{5}(\mathrm{mg} / \mathrm{l})$ & $C=0.0001 t-20.51$ & 3.45 & 5.75 & +66 & 1 & 14 & 4.60 & 4 & 2.47 & $3-5$ & 7 & 0.07 \\
\hline $\mathrm{COD} / \mathrm{BOD}_{5}$ & $\mathrm{C}=0.001 \mathrm{t}-45.1$ & 11.9 & 17.3 & +45 & 1.71 & 63 & 14.44 & 12,92 & 10.56 & / & l & 0.02 \\
\hline $\mathbf{N} / \mathbf{P}$ & $C=-0.002 t+128.4$ & 24.1 & 33.5 & -61 & 1 & 102.1 & 28.9 & 20,98 & 25.77 & / & l & 0.01 \\
\hline
\end{tabular}

$\mathbf{C}_{\mathbf{t} \mathbf{0}}$ and $\mathbf{C}_{\mathbf{t f}}$ initial and final values calculated using the regression at time to (January 2003) and tf (December 2012), Trends $(\%)=\left[\left(\mathrm{C}_{\mathrm{tf}}-\mathrm{C}_{\mathrm{t} 0}\right) / \mathrm{C}_{\mathrm{t} 0}\right] \mathrm{X} 100$; Relation $\mathbf{C} / \mathbf{t}$ : Relation: Concentration/time $\mathrm{y}=$ at+b, Min: Minimal; Max: Maximum; SD:Standard Deviation; WHO.N: World Health Organization Norm; A.N: Algerian Norm; CV: Coefficient of variation; 


\subsection{Principal Component Analysis}

The principal component analysis (PCA) was also applied to the treatment of these chemical data._Although PCA is an exploratory and descriptive method the aim of the treatment is to identify the main factors that control the chemistry of the surface water [19]. This multivariate statistical method has been widely applied to investigate the phenomena of the environment across the world [20-22] and in Algeria [23-25]. These tools multivariate statistics were used successfully to study the hydrogeochemical processes [26]. This work deals with the force of multivariate techniques to characterize hydrochemical variations in the area.

\section{RESULTS AND DISCUSSION}

\subsection{Characteristics of dam waters}

Ain Zada Dam is initially meant for irrigation, but quickly turned solely to the drinking water supply of highlands large cities such as: Setif, Bordj Bou-Arreridj, El Eulma and Bougâa with a flow of $80000 \mathrm{~m}^{3} /$ day. It is therefore an important source of drinking water for all cities in this region with more than 2 million inhabitants, which requires managers to monitor and evaluate the impact of anthropogenic pollution on the dam's physical and chemical quality of water. This characterization will be made with consideration of the trends of pollution parameters. These linear trends were determined using the instantaneous concentrations and time. The average initial and final values for the period were used to calculate these values variations (Table 1). The statistical analysis of the data shows that the mean and median are very close which indicates the representativeness of the mean and a symmetric distribution that is indicator of the regularity of the samples analysed.

The utilization of this method shows that for most parameters, slope differs significantly from zero and is progressing in opposite direction relative to the volume of water stored in the dam, with the exception of $\mathrm{pH}$, dissolved $\mathrm{O}_{2}$, orthophosphates and nitrates where the slope is respectively equal to $-4.3 \%,-13 \%,-66 \%$ and $-77 \%$. All other parameters show positive slopes that vary between $6 \%$ and $290 \%$. 
The volume of water stored in the dam fell by $35 \%$ during the period of $2003-2012$, which is consistent with the precipitations decrease (38\%) for the same period (Fig.2).

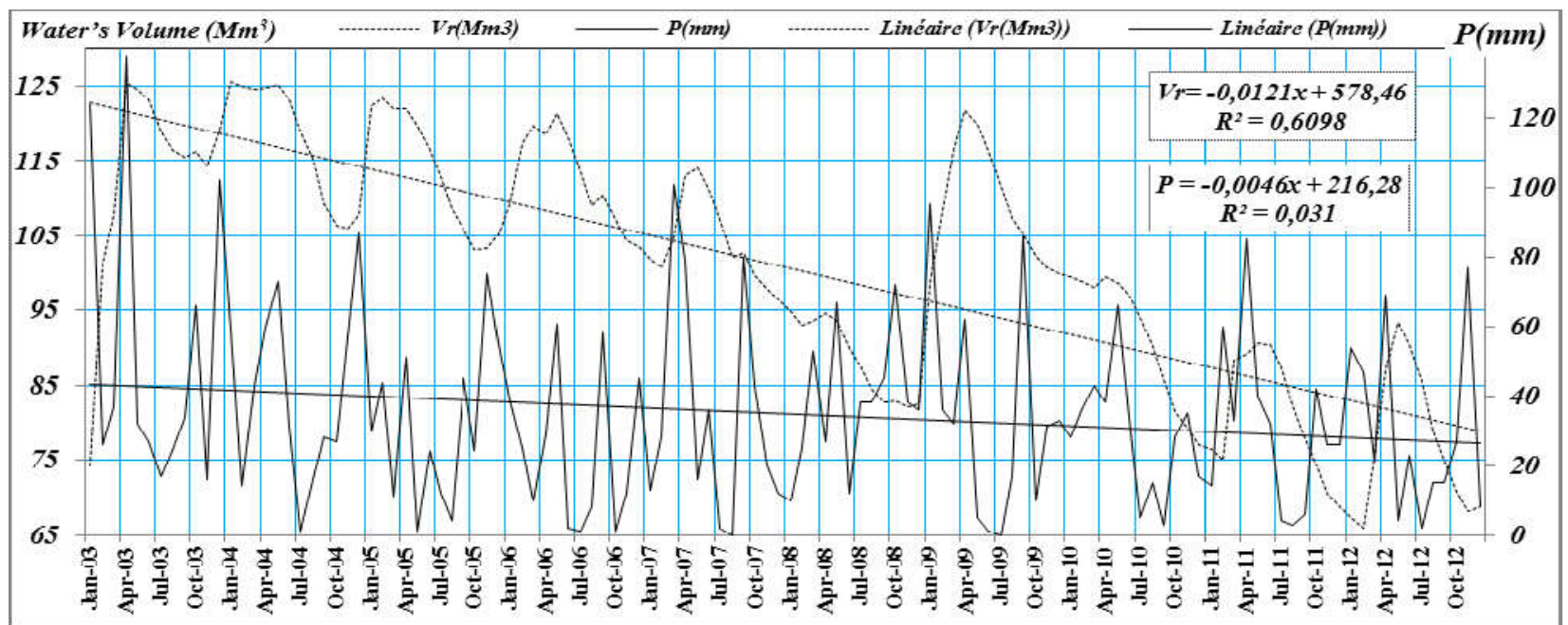

Fig.2. Monthly evolution of the water's volume and precipitation during 2003-2012

The analysis of the water temperature variation for the reservoir and the area, during this period, shows positive trends, respectively $6 \%$ and $8 \%$, (Fig.3). This is in association with the global climate change of the region.
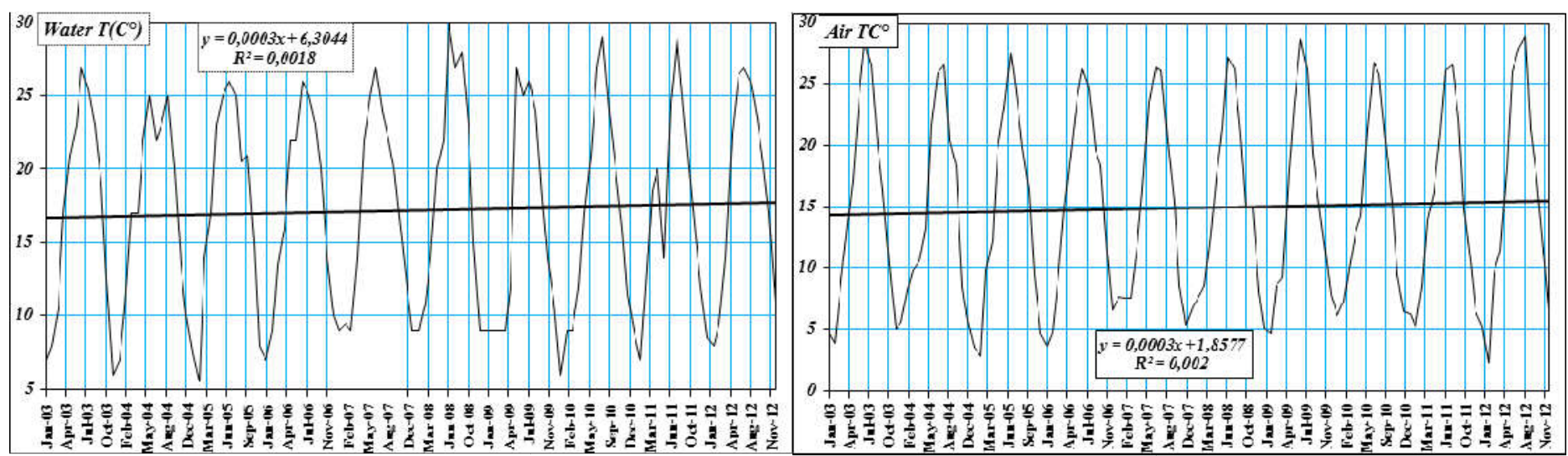

Fig.3. Variations of water and air temperatures with relevance to time during the period from 2003 to 2012

The dissolved oxygen in water reservoir has recorded a negative trend of $2 \%$, this is consistent with the decrease in $\mathrm{pH}$ of $4 \%$ (Fig.4). This is set in association with the oxidation of the organic materials according to the reaction (1) or to the increase of $\mathrm{CO}_{2}$ pressure that led to a decrease in $\mathrm{pH}$ by the formula of Kempe (2) [14]. The large surface of the water and the shallow depth of the reservoir may compensate for the oxygen consumption during the oxidation of 
organic materials, which explains the low tendency of $2 \%$ of dissolved oxygen.

$$
\begin{gathered}
\mathrm{CH}_{2} \mathrm{O}+\mathrm{O}_{2} \longrightarrow \mathrm{CO}_{2}+\mathrm{H}_{2} \mathrm{O} \\
\mathrm{CO}_{2}+\mathrm{H}_{2} \mathrm{O} \longmapsto \mathrm{H}_{2} \mathrm{CO}_{3}^{-} \longmapsto \mathrm{H}^{+}+\mathrm{HCO}_{3}^{-}
\end{gathered}
$$

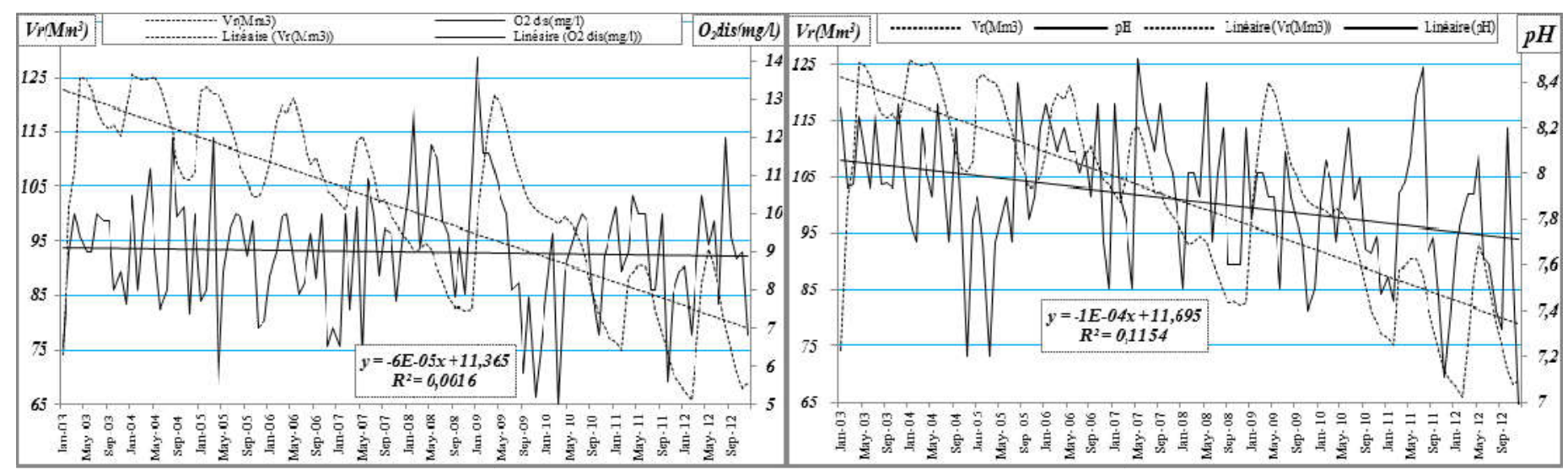

Fig.4. Variation of dissolved Oxygen $\left(\mathrm{O}_{2 \mathrm{dis}}\right)$ and the $\mathrm{pH}$ of the dam water (2003-2012) in function of water volume

The general trend of salinity represented by the electrical conductivity shows an increase of $76 \%$ (Fig.5). This increase is related to a decrease in the volume of water in the dam and the concentration of the water by intense evaporation of the water retaining.

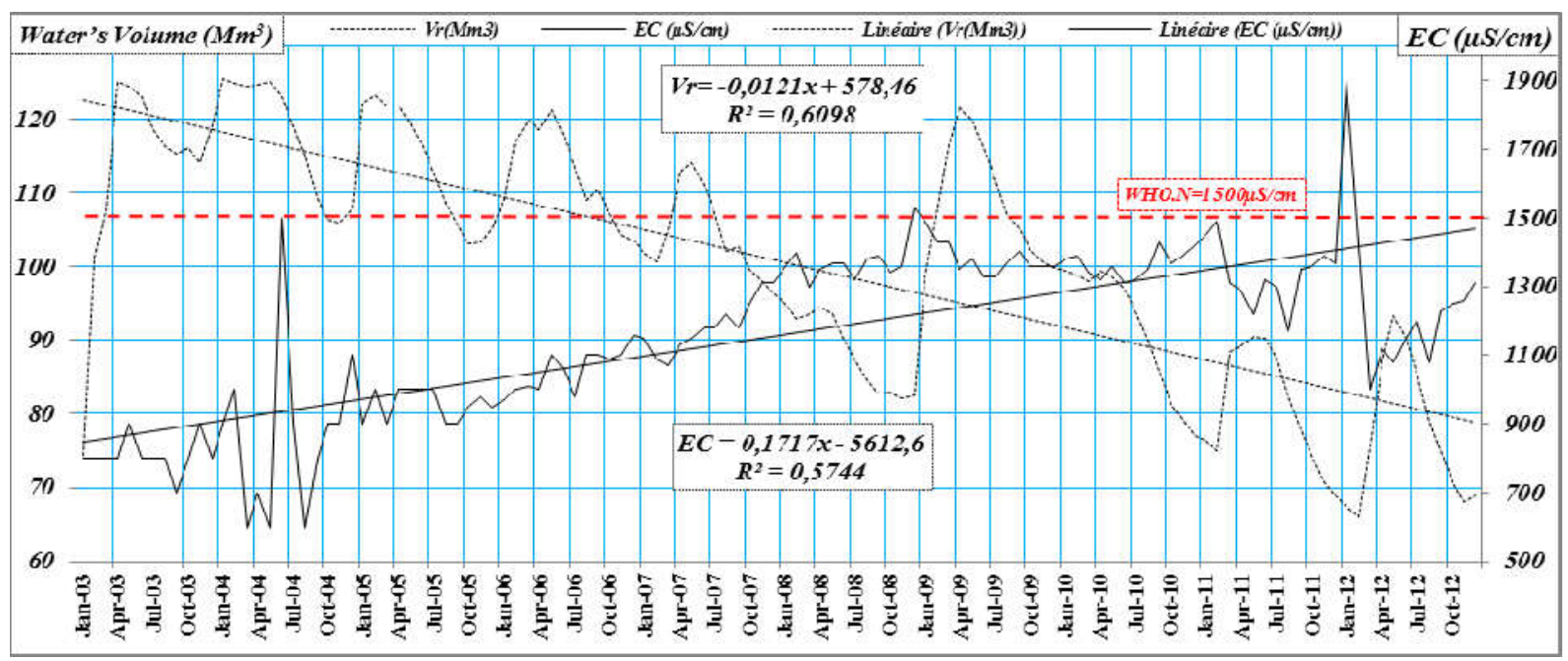

Fig.5. Changes in salinity of the dam's water in function of water volume (2003-2012)

\subsection{Organic materials}

The examination of the variation of the values of organic materials stored in the waters of the reservoir during this period shows that there was appositive trend (85\%), which is consistent 
with the positive trends of $\mathrm{COD}(88 \%)$ and the $\mathrm{BOD}_{5}(66 \%)$. The $\mathrm{COD} / \mathrm{BOD}_{5}$ ratio of more than 4 indicates the presence of organic materials readily biodegradable, (Fig. 6).

The values of COD (10 to109 mg/l) and BOD $_{5}(1-14 \mathrm{mg} / \mathrm{l})$ can be explained by the creation of conditions of degradation of organic materials by microorganisms. This degradation is accompanied by a decrease of $2 \%$ in the dissolved oxygen.

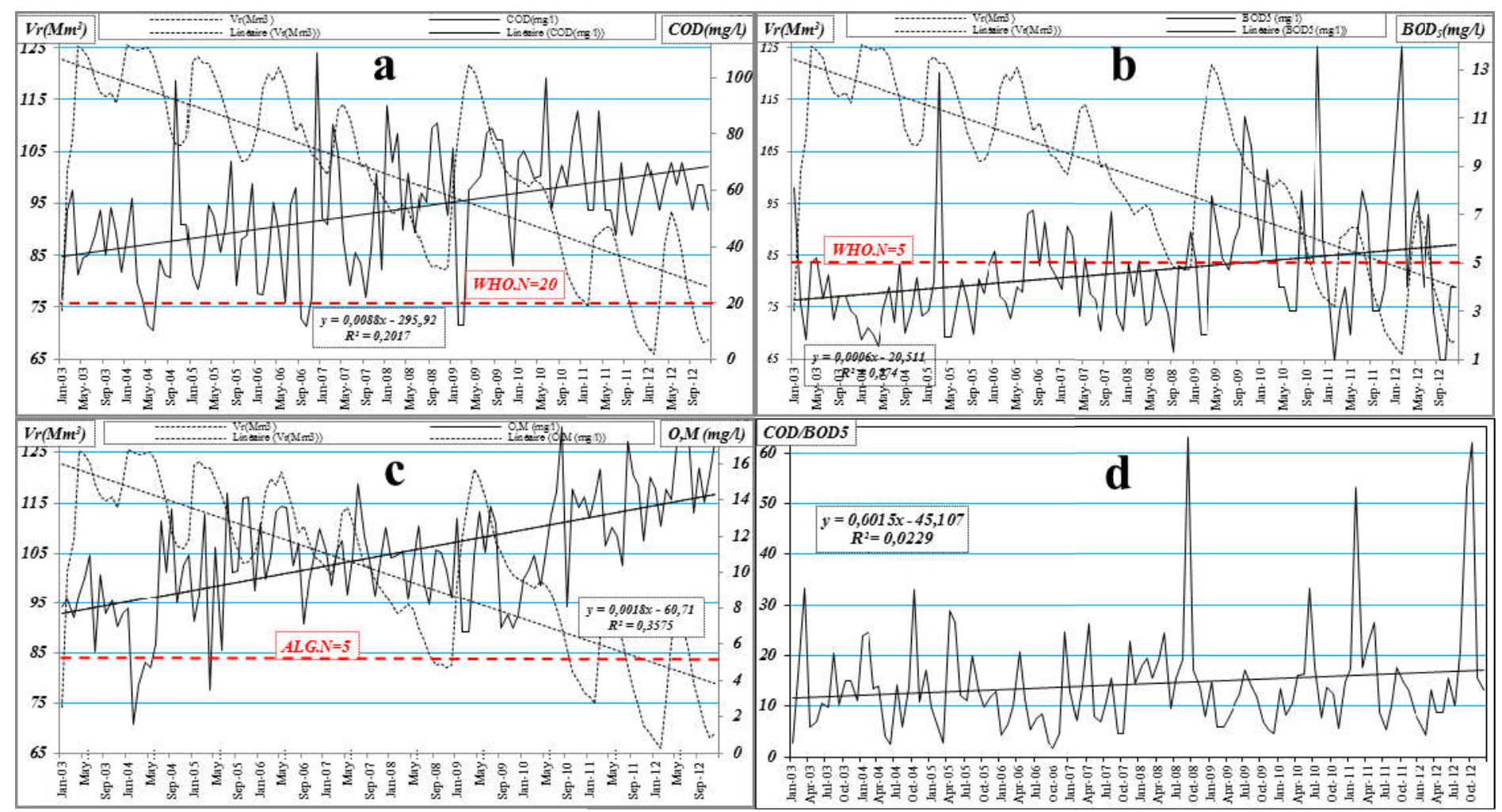

Fig.6. Variation of $\mathrm{COD}(\mathrm{a}), \mathrm{BOD}_{5}(\mathrm{~b})$, organic materials (c), in function of water volume and $\mathrm{COD} / \mathrm{BOD}_{5}$ report $(\mathrm{d})$

\subsection{Nutrients}

The nitrate $\left(\mathrm{NO}_{3}^{-}\right)$and nitrite $\left(\mathrm{NO}_{2}^{-}\right)$are ions naturally present in the environment. They are the result of nitrification of the ammonium ion $\left(\mathrm{NH}_{4}{ }^{+}\right)$in the water and soil which is oxidized to nitrite by bacteria of the genus Nitrosomonas and then to nitrate by bacteria of the genus Nitrobacter [27]. Nitrates also originate from the natural cycle of degradation of organic nitrogen [28].

Pollution by nitrogen $\left(\mathrm{NO}_{3}{ }^{-}, \mathrm{NO}_{2}{ }^{-}\right.$and $\left.\mathrm{NH}_{4}{ }^{+}\right)$depends on the wastewater dischargeand supply of farmland nutrient (spreading of livestock waste and fertilizer). Domestic wastes, industrial 
and manure are important sources of ammonia nitrogen. The most commonly used fertilizer in the Watershed of Boussellem are urea, phosphorus, potassium nitrates, ammonium superphosphate, potassium chloride, and to a lesser extent ammonium sulfate, sodium, calcium nitrates and potassium sulphate [3]. This category of Nitrogen is the largest mass and the most difficult to assess.

Trends of different forms of nitrogen show that the largest increases were recorded for $290 \%$ with ammonium and nitrite with $100 \%$ (Fig.7). This increase in ammonium in water retentionis due to (i) the quantity of organic animal and humanspilled material, (ii) the plant material streams, (iii) industrial and agricultural discharges.

While the increase in the nitrite is either ammonium oxidation or the reduction of nitrate by denitrification, according to the following reaction (3) [29].

$$
\mathrm{NH}_{4}^{+}+3 / 2 \mathrm{O}_{2}+\mathrm{H}_{2} \mathrm{O} \longrightarrow \mathrm{NO}_{2}^{-}+2 \mathrm{H}_{3} \mathrm{O}^{+}
$$

This is consistent with the reduction of nitrate, which recorded a negative trend of $77 \%$ (Fig.7). This decrease is probably due to (i) largely to its consumption by the algae (ii) followed by reduction of dissolved oxygen of $2 \%$ to turn into nitrites $\left(\mathrm{NO}_{2}{ }^{-}\right)$and to finally reduce $\mathrm{NH}_{4}{ }^{+}$. We are witnessing a natural phenomenon of denitrification due to the consumption of dissolved $\mathrm{O}_{2}$ by microorganisms present in the waters of the dam according to the formula (4).

$$
\mathrm{NO}_{3}^{-}+2 \mathrm{H}_{3} \mathrm{O}^{+}+2 \mathrm{e} \longrightarrow \mathrm{NO}_{2}^{-}+3 \mathrm{H}_{2} \mathrm{O}^{-}
$$




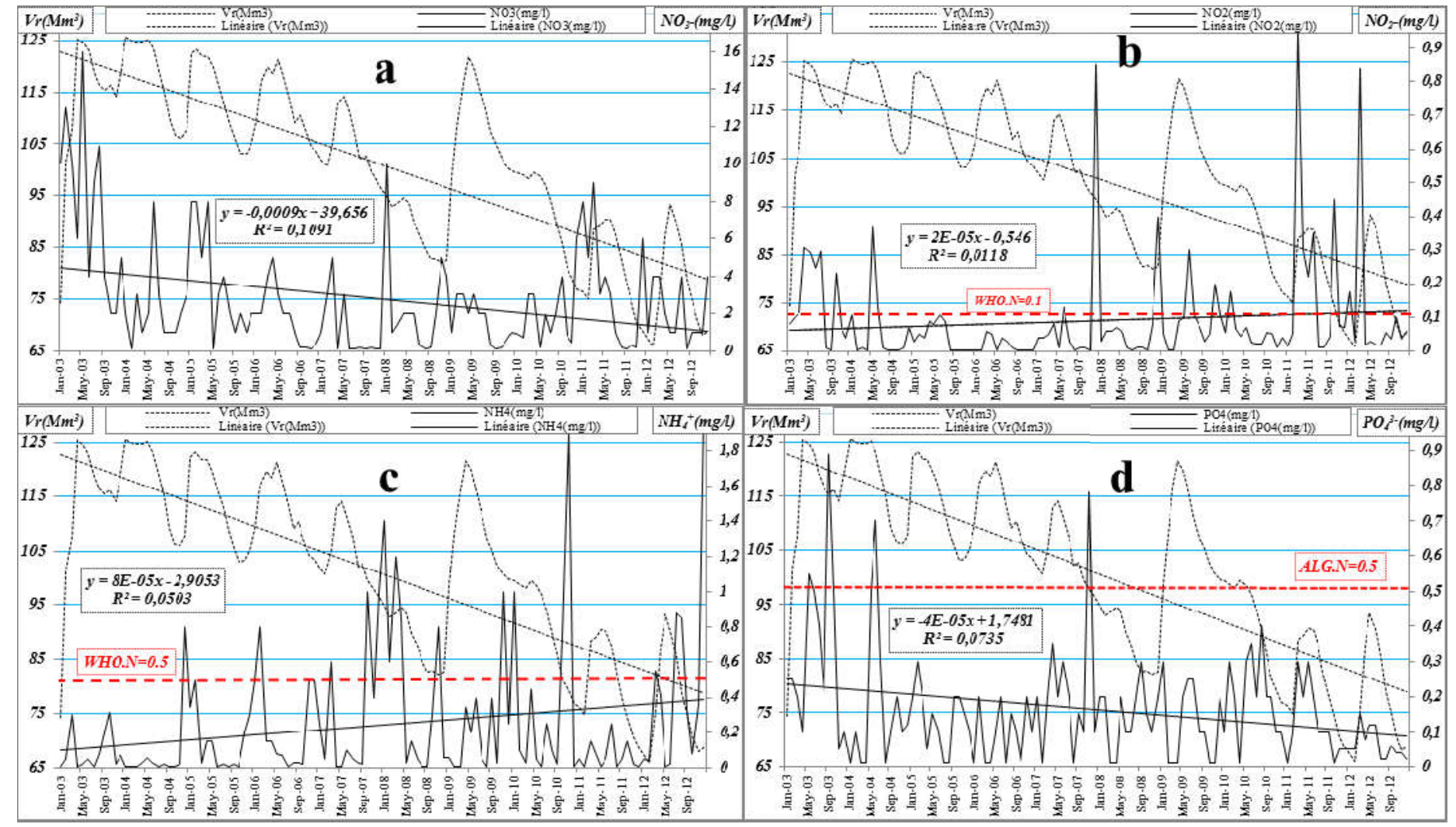

Fig.7. Nutrients variation over time. $\left(\mathrm{NO}_{3}(\mathrm{a}), \mathrm{NO}_{2}(\mathrm{~b}), \mathrm{NH}_{4}(\mathrm{c})\right.$ and $\left.\mathrm{PO}_{4}(\mathrm{~d})\right)$ in function of water volume

The relationship between the concentrations of nitrates, ammonium and nitrates in the waters of the restraint during this period shows an opposite trend of $\mathrm{NO}_{3}{ }^{-}$, compared to $\mathrm{NO}_{2}{ }^{-}$and $\mathrm{NH}_{4}{ }^{+}$. (Fig.8). Nitrates are the oxidized form of nitrogen against the other two forms; the ammonium and nitrite are reduced forms. This transformation is done by anaerobic bacteria, which promote denitrification of nitrate according to the formula (4). This passage is characterized by the reduction of nitrates in waters, indicating a change in shape. These reactions are accompanied by a decrease in oxygen in the aquatic environment.

The decrease in $\mathrm{NO}_{3}{ }^{-}$is accompanied by a decrease in the concentration of $\mathrm{PO}_{4}{ }^{3-}$, which registered an overall decline of $61 \%$. This can be explained in two ways: (i) the phosphorus is not very mobile and is readily adsorbed by soil colloids and thus removed by the mechanical erosion process [30], (ii) phosphorus concentrations are regulated in water OuedBoussellam by several biogeochemical processes such as precipitation in the form of apatite $\left[\left(\mathrm{PO}_{4}\right) 3(\mathrm{~F}, \mathrm{Cl}, \mathrm{OH}) \mathrm{Ca}_{5}\right][31]$ and consumption by aquatic plants [32-34]. 


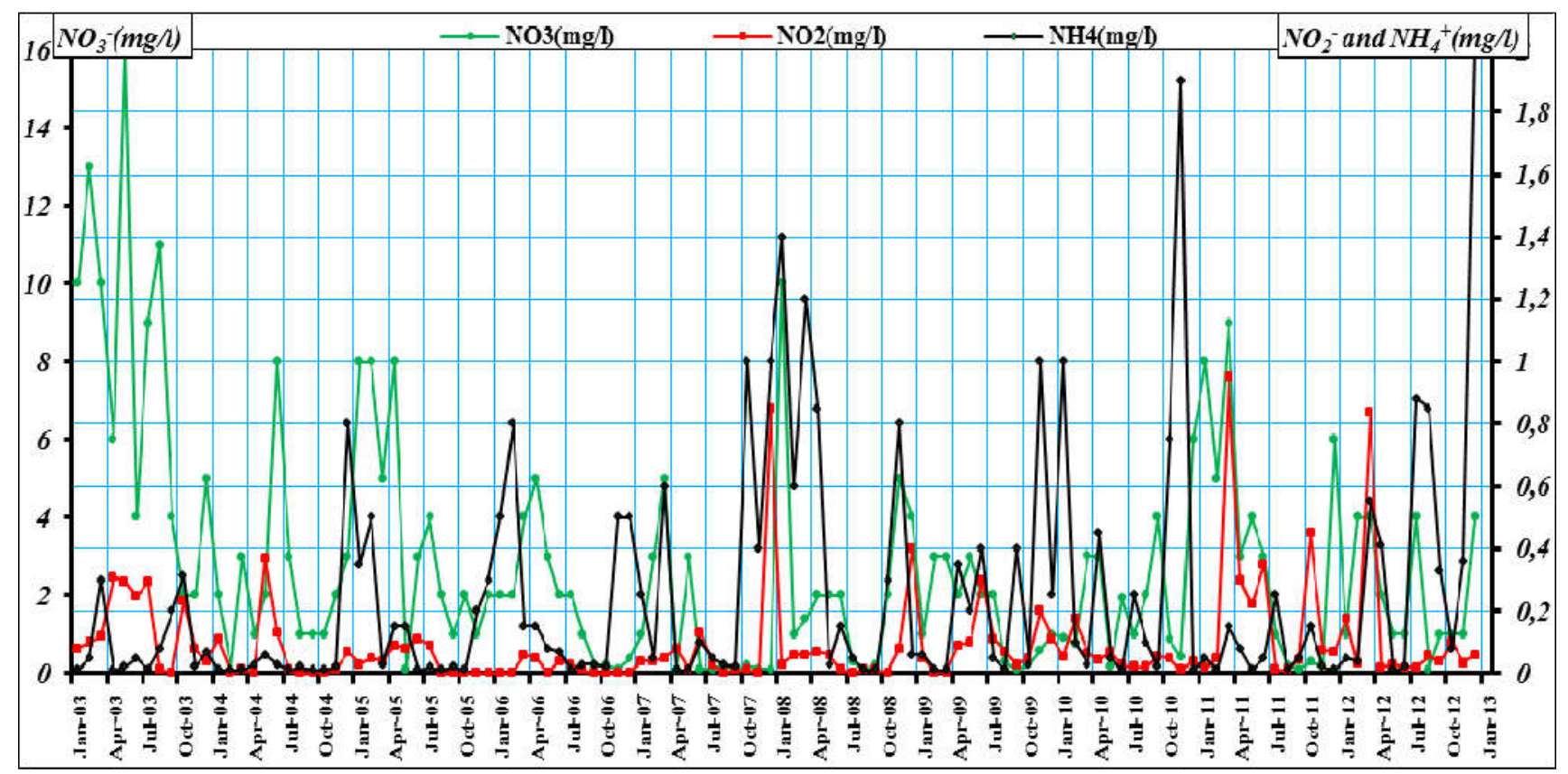

Fig.8. Evolution of the levels of nitrites, nitrates and ammonium waters of the dam (2003-2012)

\subsection{Eutrophication}

Eutrophication is a natural phenomenon that can affect water bodies especially in ecosystems whose waters renew slowly especially in shallow lakes. This action means the natural enrichment of an aquatic ecosystem nutrient. The values of NT/PT ratio, an indicator of eutrophication status of water [35] provide information on the likely presence of algae fixing atmospheric nitrogen for values of the ratio lower than 29 [36]. The trend shows a decrease of N/P ratios of $61 \%$ (Fig.9), with values ranging from 1 to 102 during the period of observation. The majority of the values are below the value of 29 , which allows the appearance of Cyanophyceae in the dam Ain Zada.

Phosphorus acts as a limiting factor in the waters, which confirms the contribution of phosphates in the late winter and spring leaching. Microorganisms develop quickly and can lead to the appearance of foam on the surface. Many strains of Cyanophyceae have a capacity to produce toxins that are dangerous for bothdrinking water or swimming [37]. 


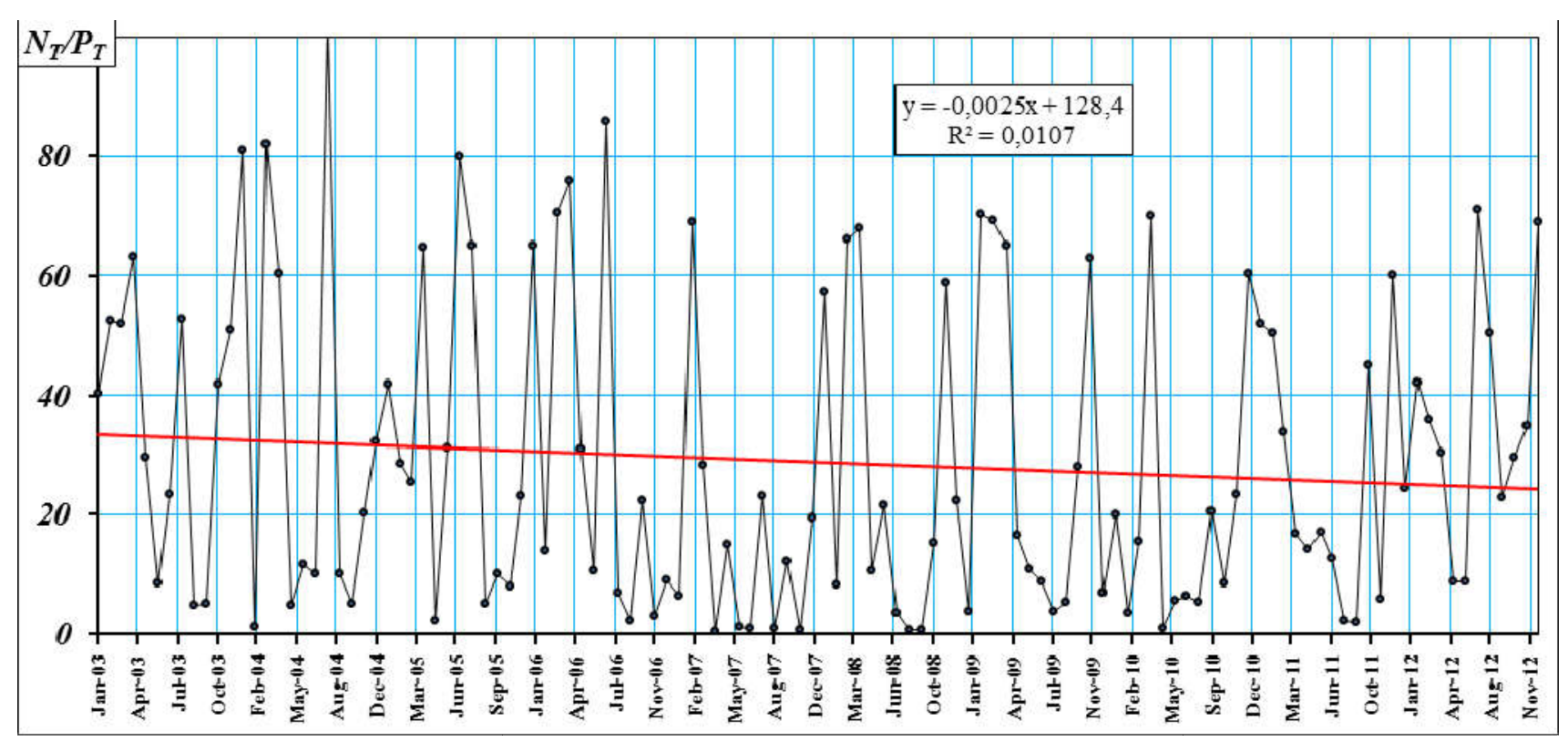

Fig. 9. Variation $N_{T} / P_{T}$ ratio in Ain Zada dam water over the period (2003/2012)

\subsection{Statistical analysis by Principal Component Analysis (PCA)}

The analysis is centered reduced that was performed on a table of 120 individuals and 13 variables ( $\mathrm{P}, \mathrm{Vr}, \mathrm{DO}, \mathrm{TW}, \mathrm{EC}, \mathrm{pH}, \mathrm{NO}_{3}, \mathrm{NO}_{2}, \mathrm{NH}_{4}, \mathrm{PO}_{4}, \mathrm{COD}, \mathrm{BOD}_{5}$ and $\left.\mathrm{OM}\right)$. The first result of this analysis is the correlation between the different variables. The correlation coefficient is commonly used to estimate the relationship between two variables. It is a simple statistical tool to show the degree of connection between the various variables. Note that for value pairs 120 , the theoretical correlation coefficient of Bravais-Pearson is 0.25 for $\alpha=0.01$. Table 2. The correlation matrix outcome of the PCA shows that P has a significant relationship ( 0.40 to 0.65 ) with Vr, Tw, EC and OM. This reflects the participation of the precipitation in the acquisition of saline load of surface water in the region and the impact of the temperature of precipitation in the temperature of the water of dam. The precipitation has also the impact of the concentration of the organic matter (OM) leaching .DO has a significant relationship (-0.27 to 0.26$)$ with $\mathrm{NO}_{3}$, $\mathrm{NO}_{2}, \mathrm{NH}_{4}, \mathrm{PO}_{4}$ and $\mathrm{BOD}_{5}$ reflecting an oxidation and reduction of nutriment and the organic matter. Tw influences EC $(r=0.47)$ and the oxidation of organic matter $(r=0.33)$. Oxidation of $\mathrm{OM}$ frees $(\mathrm{H}+)$ according to equation (5) [38] which provides a good connection with the OM, $\mathrm{COD}$ and $\mathrm{pH}(\mathrm{r}=0.28$ and $\mathrm{r}=0.55)$ respectively. Nitrogen elements are also well correlated $(-0.28<\mathrm{r}<0.34)$. 


$$
\mathrm{FeS}_{2}+7 / 2 \mathrm{O}_{2}+\mathrm{H}_{2} \mathrm{O} \longrightarrow \mathrm{Fe}_{2}^{+}+2 \mathrm{SO}_{4}{ }^{2-}+2 \mathrm{H}^{+}
$$

Table 2. Pearson coefficients correlation for physicochemical parameters at the 0.01 level and $n=120$.

\begin{tabular}{cccccccccccccc}
\hline & $\mathbf{P}$ & $\mathbf{V r}$ & $\mathbf{O D}$ & $\mathbf{T w}$ & $\mathbf{E C}$ & $\mathbf{p H}$ & $\mathbf{N O}_{\mathbf{3}}$ & $\mathbf{N O}_{2}$ & $\mathbf{N H}_{\mathbf{4}}$ & $\mathbf{P O}_{\mathbf{4}}$ & $\mathbf{C O D}$ & $\mathbf{B O D}_{\mathbf{5}}$ & $\mathbf{O M}$ \\
\hline $\mathbf{P}$ & 1,00 & & & & & & & & & & & & \\
$\mathbf{V r}$ & $\mathbf{0 , 6 5}$ & 1,00 & & & & & & & & & & & \\
$\mathbf{O D}$ & 0,22 & 0,33 & 1,00 & & & & & & & & & & \\
$\mathbf{T w}$ & $\mathbf{0 , 4 0}$ & $\mathbf{0 , 5 2}$ & 0,22 & 1,00 & & & & & & & & & \\
$\mathbf{E C}$ & $\mathbf{0 , 5 0}$ & $\mathbf{- 0 , 8 7}$ & 0,13 & $\mathbf{0 , 4 7}$ & 1,00 & & & & & & & & \\
$\mathbf{p H}$ & 0,14 & $\mathbf{- 0 , 7 7}$ & 0,14 & 0,10 & 0,15 & 1,00 & & & & & & & \\
$\mathbf{N O}_{\mathbf{3}}$ & 0,08 & $\mathbf{- 0 , 2 7}$ & $\mathbf{- 0 , 2 7}$ & 0,18 & 0,24 & 0,12 & 1,00 & & & & & & \\
$\mathbf{N O}_{\mathbf{2}}$ & 0,09 & 0,11 & $\mathbf{0 , 2 6}$ & 0,09 & $-0,02$ & 0,14 & $\mathbf{- 0 , 2 8}$ & 1,00 & & & & & \\
$\mathbf{N H}_{\mathbf{4}}$ & $-0,14$ & $\mathbf{- 0 , 3 9}$ & $\mathbf{0 , 2 5}$ & 0,18 & 0,13 & 0,11 & $\mathbf{0 , 3 0}$ & $\mathbf{0 , 3 4}$ & 1,00 & & & & \\
$\mathbf{P O}_{\mathbf{4}}$ & $-0,12$ & $\mathbf{- 0 , 2 7}$ & $\mathbf{0 , 2 3}$ & $-0,14$ & $-0,21$ & $-0,22$ & $-0,11$ & 0,16 & $-0,11$ & 1,00 & & & \\
$\mathbf{C O D}_{\mathbf{O}}$ & 0,23 & $\mathbf{- 0 , 4 5}$ & 0,20 & $\mathbf{0 , 2 7}$ & 0,17 & $\mathbf{0 , 2 8}$ & 0,18 & $-0,06$ & 0,11 & $-0,05$ & 1,00 & & \\
$\mathbf{B O D}_{\mathbf{5}}$ & 0,20 & $\mathbf{- 0 , 2 8}$ & $\mathbf{- 0 , 2 4}$ & 0,24 & 0,18 & 0,23 & 0,13 & $-0,06$ & 0,22 & $-0,10$ & 0,21 & 1,00 & \\
$\mathbf{O M}^{\mathbf{0 , 4 1}}$ & $\mathbf{- 0 , 6 0}$ & 0,05 & $\mathbf{0 , 3 3}$ & 0,14 & $\mathbf{0 , 5 5}$ & 0,04 & 0,06 & 0,23 & $-0,11$ & $\mathbf{0 , 3 2}$ & 0,16 & 1,00 \\
\hline
\end{tabular}

The bold values indicate the correlated variables.

The second result of this analysis is liaison between the different variables and factors because it used to examine the underlying patterns for a large number of variables and to determine the possible contributing factors in the hydrochemistry of waters samples. The Kaiser criterion [39] was applied to determine the total number of significant factors. According to this criterion, only factors that eigenvalue greater than or equal to 1 have been retained as a possible source of variance in the data. Table 3. Two factors (F1 and F2) were selected and represent more than $65.52 \%$ of the total variance, which is quite good and can be used to identify major changes in water chemistry. F1 represents $54.59 \%$ of the variance and is positively determined by $\mathrm{P}, \mathrm{Vr}, \mathrm{Tw}, \mathrm{EC}, \mathrm{pH}, \mathrm{COD}$; $\mathrm{BOD}_{5}$ and $\mathrm{OM}$. This factor is the factor of contamination by organic matter, wastewater and industrial. F2, which represents $10.93 \%$ of the total variance, is positively determined by $\mathrm{DO}$, nitrogen and $\mathrm{PO}_{4}$. This is the factor of agricultural pollution.

These two factors indicate that surface water in the region, following two pollutions, of wastewater and industrial, and by irrigation water. 
Table 3.Variance explained and component matrixes

\begin{tabular}{|c|c|c|}
\hline Components & F - 1 & F- 2 \\
\hline $\mathbf{P}$ & $-0,671814$ & $-0,207112$ \\
\hline $\mathbf{V r}$ & $-0,932735$ & $-0,059733$ \\
\hline OD & $-0,430978$ & $\mathbf{0 , 5 9 5 7 8 4}$ \\
\hline $\mathbf{T w}$ & $-0,629877$ & $-0,035159$ \\
\hline EC & $-0,843918$ & 0,067898 \\
\hline pH & $-0,753281$ & $-0,237152$ \\
\hline $\mathrm{NO}_{3}$ & $-0,305058$ & 0,607400 \\
\hline $\mathrm{NO}_{2}$ & $-0,678766$ & 0,760920 \\
\hline NH4 & $-0,013145$ & 0,5141997 \\
\hline $\mathrm{PO}_{4}$ & 0,307279 & 0,393568 \\
\hline COD & $-0,533702$ & 0,159016 \\
\hline BOD $_{5}$ & $-0,412049$ & 0,235953 \\
\hline OM & $-0,642515$ & $-0,306680$ \\
\hline Expl.Var & 4,49 & 1,42 \\
\hline Prp.Totl (\%) & 54.59 & 10.93 \\
\hline Cumul - \% & 54.59 & 65.52 \\
\hline
\end{tabular}

The bold values indicate the correlated variables.

\section{CONCLUSION}

The aim of our study was to determine the influence of urban, agricultural and industrial discharges on Ain Zada's dam waters. The chemical composition of these waters was determined; the temporal evolution of some physico-chemical parameters was tracked for a period of ten years. The statistical study by a Principal Components Analysis (PCA) highlights the relationship between the chemical parameters responsible for the pollution. It indicates that the dam surface waters are contaminated by industrial, irrigation and waste-water.

The results show that all sources of pollution are present, whether natural, industrial, agricultural or urban. Most chemical elements are connected with urban planning, fertilizers and effluent increased in the dam during this period: E.C (76\%), MO (85\%), COD (88\%), $\mathrm{BOD}_{5}(66 \%), \mathrm{NO}_{2}^{-}(100 \%), \mathrm{NH}_{4}^{+}(290 \%)$. This degradation of the quality of the water is due to the decomposition of organic material that is accompanied by a decrease in $\mathrm{pH}$ of $4.3 \%$, a temperature increase of $8 \%$, and a reduction of $38 \%$ precipitation followed by reducing the volume of reservoir water by $35 \%$. This has led to the concentration of chemical elements in 
the waters of the dam. The increase is due to ammonium significant amount of organic material and industrial wastes. There has also been a reduction of nitrates and phosphates, but an increase of nitrites is due to the ammonium oxidation, accompanied by a decrease of the dissolved oxygen of $2 \%$.

Water dam Ain Zada seems to become more and more polluted as most surface waters in eastern Algeria. $93 \%$ of the samples exceed the content of $0.1 \mathrm{mg} / 1 \mathrm{NO}_{2}{ }^{-}$and $31 \%$ of samples exceeded the level of $0.5 \mathrm{mg} / 1 \mathrm{NH}_{4}{ }^{+}$recommended by the Algerian standard.

\section{ACKNOWLEDGEMENTS}

The authors are grateful to the authorities of Setif and BBA for providing data and permitting to pursue and publish the present work. The Authors thank also all technicians of National Agency of Water Resources for their assistance and support in achieving chemical analyzes.

\section{REFERENCES}

[1] Belhadj MZ, Boudoukha A and Mezedjri L. Quality of surface waters and their impact on the environment in the wilaya of Skikda (North-eastern Algeria) (Natural Mercury contamination). European Journal of Scientific Research., 2011, 56, 2, 204-211.

[2] Souaad BL and Belkheir D. Study of the phenomenon of eutrophication in Dam Hammam Boughrara (Wilaya of Tlemcen, Algeria). Hydrological Sciences Journal., 2012, 57(1).

[3] Boudoukha A and Boulaarak M.Waters pollution of Hammam Grouz Dam by nutrients (East of Algeria). Bull Serv Geol., 2013, 24 (2).

[4] Guizani M, Fujii T, Hijikata N and Funamizu N. Salt removal from soil during rainy season of semi-arid climate following an assumed salt accumulation from previous cultivations fertilized with urine. Euro-Mediterranean Journal for Environmental Integration., 2016, 1(1).

[5] Sakhel SR, Geissen SU, and Vogelpohl A. Virtual industrial water usage and wastewater generation in the Middle East and North Africa 2011-2015. Euro-Mediterranean Journal for Environmental Integration. 2017, 2(1). 
[6] Bennacer L, Fekhaoui M, Benoit-Guyoud J and Merlin G. Influence of tide on water quality of Sebou polluted by Gharb plain wastes (Morocco).Water Research.,1997, 31, 4, 867-887.

[7] Boudoukha A and Bouguerne A. Heavy metals in surface waters of Oued Boussellem; discussion of analytical data. Geomaghreb., 2010, 6, 97-104.

[8] Mebarkia A. Studies of physico-chemical characteristics of surface waters.Case of the dam Ain zada wilaya of Bordj Bou-Arreridj.(North-easternAlgeria). Magister dissertation. Univ. Annaba., 2011, 209 p.

[9] Bouguerne A, Boudoukha A, Benkhaled A, and Mebarkia AH. Assessment of surface water quality of Ain Zada dam (Algeria) using multivariate statistical techniques. International Journal of River Basin Management., 2016, 1-11.

[10] Vila JM. The Alpine chain of oriental Algeria and the Algerian-Tunisian confines. Doctoral thesis es-science Pierre et Marie curie University, Paris VI., 1980, 665 p.

[11] Hadji R, Chouabi A, Gadri L, Raïs K, Hamed Y and Boumazbeur A. Application of linear indexing model and GIS techniques for the slope movement susceptibility modeling in Bousselam upstream basin, Northeast Algeria. Arabian Journal of Geosciences., 2016, 9(3), 1-18.

[12] Bouguerne A. Comparative study by hydrological and hydrochemical analysis of surface waters watersheds of oued Bousselem and Oued Rhumel.Magister Dissertation Dep. Hydrau. Univ. Batna., 2001,252 p.

[13] Wilder HB and Simmons CE. Programme for evaluating stream quality in North Carolina. USGS Wat. Supply Pap., 1982, 2185A, 1-15

[14] Kempe S. Long-termrecords of the C07 pressure fluctuations in fresh water. Mediterreen Geology Palaontology Institut., 1982, 52, 291-332.

[15] Harned D and Meyer D. Water quality of the Yadkin-Pee River system, North Carolina. Variability, pollution loads and long termtrends. USGS Water Supply Pap., 1983. 2185E.

[16] Regnie S. On some mathematical aspects of automatic classification problems.Math and Human Sciences., 1965, 82, pp.13-29.

[17] Hirsch RM, Slack JR and Smith RA. Techniques of trend analysis for monthly water 
quality data. Wat. Resour. Res., 1982, 18 (1), 107-121.

[18] Smith RA, Hirsch RM and Slack JR. A study of trends in total phosphorus measurements at NASQAN stations. USGS Wat. Supply Pap., 1982, 2190.

[19] Dagnélie P. Statistique théorique et appliquée. Tome 2 : Inférences à une et à deux dimensions. Edis Boeck \& Larcier, Bruxelles-Univ. 2006.

[20] Anazawa K and Ohmori H. The hydrochemistry of surface waters in AndesiticVolcanic area, Norikura volcano, central Japan. Chemos., 2005, 59, 605-615.

[21] Güler C and Thyne G. Hydrologic and geologic factors controlling surface and Groundwater chemistry in Indian wells-Owens Valley area, southeastern California, USA. J. Hydro., 2004, 285, 177-198

[22] Güler C, Thyne G, McCray J and Turner A. Evaluation of graphical and multivariate statistical methods for classification of water chemistry data. Hydro Journal., 2002, 10, 455-474.

[23] Tiri A, Lahbari N and Boudoukha A. Multivariate Statistical Analysis and Geochemical Modeling to Characterize the Surface Water of Oued Chemora Basin, Algeria. Nat Res Resa., 2014, 23, 379-391.

[24] Tiri A, Lahbari N and Boudoukha A. Hydrochemical characterization of surface water in the Timgad watershed, East Algeria. Desalination and Water Treatment., 2014.

[25] Guerraiche Z, Boudoukha A, Benkadja R. Variation of the chemical composition of Grouz dam waters (Eastern Algeria). Desalination and Water Treatment., 2014.

[26] Cameron E, The hydrochemistry of the Fraser River, British Columbia: seasonal variation in major and minor components. J Hydr., 1996, 182, 209-215.

[27] Health Canada. Nitrate and Nitrite. Recommendations for the quality of drinking water in Canada-Supporting Documentation., 1992, Available from: www.hc-sc.gc.ca/ehp/dhm/catalogue/dpc pubs/rqepdoc_appui/nitrate.pdf.

[28] Kone M, Bonu L, Bouvet Y and Koulidiaty J. Study of water pollution from agricultural inputs: for five intensive agricultural areas of Burkina Faso. Sid Science and Technology., $2009,17,6-15$.

[29] Martin G. The nitrogen problem in the waters.Technical and Documentation., 1979, Paris 
ed $279 \mathrm{p}$.

[30] Sharpley AN. The enrichment of soil phosphorus in runoff sediment. Journal Environmental Quality., 1980, 9(3), 521-526.

[31] Golterman HL and Meyer ML. The geochemistry of two hard water rivers, the Rhine and the Rhone: Part 4: The determination of the solubility product of hydroxy-apatite. Hydrobiologia., 1985, 126, pp. 25-29.

[32] Johnsono AH, Bouldin DR., Goyette EA and Hedges AM. Phosphorus loss by stream transport from a rural watershed: quantities, processes and sources. Environmental Journal Quality., 1976, 5 (2), 148-157.

[33] Probst JL. Nitrogen and phosphorus exportation in the Garonne basin (France). Hydrology., 1985, 76, 281-305.

[34] Pilleboue E and Dorioz JM. Mass balance and transfer mechanisms of phosphorus in arural watershed of lac Léman, France. In: Sediment and Water Interaction (Proc. 3rd Sediment,Freshwater Symp.) (ed. by P. G. Sly),. 1986, 91-102.

[35] Seip KL. Phosphorus and nitrogen limitation of algal biomass across trophic gradients. Aquatic Sciences., 1994, 56 (1), 16-28.

[36] Downing JA. and Mccauley E. The nitrogen: phosphorus relationship in lakes. Limnology and Oceanography., 1992, 37, 936-945.

[37] Duchemin J. Blue-green algae, cyanophyceae, cyanobacteria. Water and Health. Normandie., 2010, 22 p.

[38] Kaiser HF. The application of electronic computers to factor analysis. Educ Psychol Meas., 1960, 20, 141-151.

[39] Droubi A, Cheverry C, Fritz B and Tardy Y. Géochimie des eaux et des sels dans les sols des polders du lac Tchad: Application d'un modèle thermodynamique de simulation de l'évaporation. Chemical Geology. 1976., 17, 165-177.

\section{How to cite this article:}

Mebarkia A, Haouchine A, Boudoukha A, and Nedjai R. Assessing of water pollution of Ain Zada dam by nutrients (North-east of Algeria). J. Fundam. Appl. Sci., 2017, 9(3), 1358-1377. 